\title{
Taxing wealth: general principles, international perspectives and lessons for Brazil
}

\author{
Tributação da riqueza: princípios gerais, \\ perspectivas internacionais e lições para o Brasil
}

\author{
MARC MORGAN*,** \\ PEDRO CARVALHO JUNIOR $x, x \times$
}

\begin{abstract}
RESUMO: O debate sobre tributação da riqueza está novamente sujeito a um grande interesse devido às propostas que saem do ciclo eleitoral dos EUA e ao crescente aumento da desigualdade da riqueza no mundo. Este artigo debate a tributação da posse da riqueza e de sua transferência entre gerações (o imposto sobre fortunas e o imposto sobre heranças), analisando a experiência internacional e extraindo lições para o Brasil. O "Imposto sobre Grandes Fortunas" nunca foi implementado e o "Imposto sobre Heranças", em nível estadual, tem sido enfraquecido ao longo do tempo. Portanto, considerando a experiência histórica e as pesquisas atuais, nós propomos um modelo de implementação e maior progressividade destes dois impostos, apesar de importantes restrições no campo da economia política.
\end{abstract}

PALAVRAS-CHAVE: Imposto sobre a riqueza; imposto sobre a herança; desigualdade.

ABSTRACT: The international debate on wealth taxation has been subject to renewed interest amid new proposals coming out of the US electoral cycle and the salience of wealth inequality. This article reviews the case for taxing wealth and its transfer across generations (wealth and inheritance taxes), analyzing their design from an international comparative perspective, and extracting lessons for Brazil. The long-debated "Tax on Large Fortunes" has never been implemented and the state-level "Tax on Inheritances" has been watered down over time. We propose a framework for the progressive implementation and reform of both taxes in the country. We argue, given the historical record and current research, that

\footnotetext{
* Senior Researcher and Western Europe Coordinator of World Inequality Lab, Paris School of Economics, Paris, France. E-mail: marc.morgan@psemail.eu. Orcid: https://orcid.org/0000-0002-1761-4346. * Doctor in Economics, Paris School of Economics.

x Senior Researcher at Instituto de Pesquisa Econômica Aplicada - IPEA, Rio de Janeiro/RJ, Brasil. E-mail: Pedro.carvalho@ipea.gov.br. Orcid: https://orcid.org/0000-0002-5015-8944.

xx PhD in Tax Policy, University of Pretoria, South Africa. Submitted: 15/January/2020; Approved: $27 /$ Abril/2020.
} 
they are technically and administratively feasible propositions, notwithstanding important political economy considerations.

KEYWORDS: Wealth tax; inheritance tax; inequality.

JEL Classification: H24; H29.

\section{INTRODUCTION}

The distributive function of taxation is becoming increasingly relevant in a context of rising income and wealth inequality across much of the world (Alvaredo et al., 2018). In this article, we consider an important component of a progressive tax system: the taxation of wealth. This comprises taxes on the aggregate value of an individual's wealth - real estate, deposits, equities, bonds, business capital, etc. - whether it is accumulated within generations (wealth taxes) or transferred across generations (estate and inheritance/gift taxes). The first are recurrent taxes levied annually, while the second are typically once-off taxes.

In Brazil, economic inequality is seen as an important social problem, particularly top-end concentration (Barros et al., 1995; Hoffmann, 2002; Medeiros, 2006; Soares, 2010; Souza, 2018). Brazil's inequality is also weakly affected by the existing personal income tax due to a mix of regressive exemptions and low marginal tax rates (Morgan, 2017; Gobetti and Orair, 2017). It is in this context that we discuss the potential for wealth and inheritance taxes as an added redistributive instrument in Brazil.

But why tax wealth in the first place? There are multiple reasons, which have to do with the nature of wealth and its implications in a market-economy with private property. First, much of private wealth is collectively determined, making it difficult to isolate individual contributions to its overall monetary value. Here we can think about the effects of central bank monetary policies on the value of financial assets and liabilities; the conventional herd-like behavior of stock markets; the effects of urbanization and public housing supply on real estate prices; public investment in infrastructure, R\&D and innovation; the contribution of the workforce to the productivity and profitability of firms; and so on. Second, an important part of wealth is due to circumstances. In this case, we may think of those "born into wealth" through inheritance. Third, the accumulation of wealth amid high and rising inequality can thwart the proper functioning of democratic institutions from the interests of the wider public to those of a narrow "elite", who can use their economic power to influence the legislative process.

During the $20^{\text {th }}$ century, advanced democracies, like the USA and the UK, levied high progressive taxes on estates passed down among generations, with top marginal rates reaching $70 \%$ and $80 \%$ on the highest inheritances at their peak in the mid-century (Piketty, 2014). Many other countries followed suit, understanding inheritance as a powerful driver of unearned inequality and a threat to highlycherished meritocratic values. Beyond meritocratic principles, the inheritance tax 
also receives the backing of mainstream ("neoclassical") economists, since it is theorized to not interfere in the allocation of an individual's time between work and leisure (Gronau, 1977). However, while popular among academics and policymakers, it one of the most sensitive taxes for ordinary citizens, given the sentimental motives attached to bequest and the low perceived salience of inherited wealth (Bastani and Waldenström, 2019).

On the other hand, annual wealth taxes are more salient for the majority of the population, as low rates and high thresholds are generally applied. Yet, they have been used a lot less frequently throughout history. This may have been due to the exceptional egalitarian leveling of the wealth distribution in the past, from exogenous shocks (wars) and endogenous policies that many countries experienced or implemented (high inheritance taxes, capital levies, capital controls, nationalizations, interest rate ceilings, rent controls, public housing initiatives, etc.). However, in recent decades, this alignment of factors has ceased to exist. The combination of financial deregulation with government de-nationalization, and capital and trade liberalization, has paved the way for rising inequality in the "neo-liberal" age. This gives the recurrent wealth tax greater relevance as a tool to deal with inequality and its social problems.

The remainder of the article is structured as follows. Second section covers the wealth tax, its rationale, structure, valuation issues and international experience. Third section assesses the inheritance tax from an international comparative perspective. The fourth section examines the wealth tax and inheritance tax in the Brazilian context. We conclude with political economy remarks in the last section.

\section{WEALTH TAX}

Owning capital assets brings a level of financial security, independence, and influence that cannot be compared to the income level of an individual. Indeed, through its command over economic resources, a high level of accumulated wealth results in disproportionate political power and rent-seeking (Bowles, 2012; Oxfam, 2014; Iara, 2015).

For these reasons, supporters of wealth taxation, such as Rudnick and Gordon (1996), argue that progressive income taxation cannot be the only strategy to improve tax fairness. Many authors, such as Diamond and Saez (2011) and Jacobs (2013), have criticized the high reliance placed on labor taxation, as opposed to capital and wealth taxation. Payroll taxes, like consumption taxes, generally have low incidence among the wealthiest individuals. The introduction of a progressive wealth tax would at least mitigate this unequal division of the tax burden, as wealth itself is highly unequally distributed within countries (Alvaredo et al., 2018). Moreover, most advanced economies levy local property taxes on real estate, which is the main wealth asset among families within the middle $70 \%$ of the wealth distribution (Alvaredo et al., 2018; Saez and Zucman, 2019). A progressive wealth tax 
on all asset categories would be better able to effectively tax the wealthiest fortunes, which are disproportionately composed of financial assets (ibid.).

On the other hand, there are authors, like Denk (2012), who argue that wealth taxes discourage saving and asset accumulation among generations and encourage capital flight to tax heavens. They also highlight that recurrent wealth taxes are unfeasible, especially in developing countries, due to high administrative costs. These challenges can be overcome with adequate attention to design and logistics. If wealth taxes were to have few exemptions and high initial thresholds, only a small fraction of the population would be affected, and resources could be redirected to increase the savings of the rest of the population (Saez and Zucman, 2019). ${ }^{1}$ Tax avoidance and evasion can be mitigated with third-party reporting of assets and a weakening of offshore financial centers. ${ }^{2}$ For example, minor response elasticities of less than 1 are found in Sweden (Seim, 2017), the Netherlands (Zoutman, 2018), and in Denmark (Jakobsen et al., 2018) - countries with extensive third-party reporting of wealth. ${ }^{3}$ In countries with weak enforcement, such as Colombia, this elasticity is twice or three times as high (Londoño Velez and Ávila-Maheca, 2018). Much larger elasticities are found in countries with weak or no third-party reporting, and sub-national taxation, such as Spain (Durán-Cabé et al., 2019), and Switzerland (Brülhart et al., 2019), where a 0.1 percentage point increase in wealth taxation lowers reported wealth by up to $3.5 \%$ in total. ${ }^{4}$

The administrative costs of implementing a wealth tax have to be weighed up against its potential benefits, noting that the information technology to properly administer them is readily available to many countries, less-developed included. For instance, tax administrations can make use of databases on local property taxes to establish real estate values, which only requires cooperation agreements among different tiers of government. Property values can be verified both by acquisition values from notaries or by up-to-date market values from real estate sector entities. In addition, the use of Computer Assisted Mass Appraisal has substantially reduced the administrative costs of valuations. Other non-financial assets can be reported at their acquisition value, accounting for depreciation, or by business surveys that compile their average market values.

Regarding financial assets, tax administrations can compel financial institu-

\footnotetext{
${ }^{1}$ The implied assumption here that a high concentration of financial saving leads to more productive investment in society than otherwise is questionable, not only in theory but in practice. It can be argued that wealth taxes de-concentrate ownership of assets among individuals without affecting investment decisions or innovation, as these are taken in the context of competing enterprises emulating one another.

${ }^{2}$ The dis-use of these centers by national residents can be achieved unilaterally via economic sanctions from economically large countries. However, multilateral cooperation would be more effective. We return to these issues in the fourth section.

${ }^{3}$ An increase in the average wealth tax of 1 percentage point reduces declared taxable wealth by less than $1 \%$.

${ }^{4}$ It should be noted that these estimates are drawn from very small changes in sub-national tax rates. In the Spanish case, the estimates only correspond to the region of Catalonia.
} 
tions to provide information on the assets of their clients. In the case of an open market security, its value can be defined as the average price during the fiscal year. Bank deposits can be valued as the higher value between the total balance in the last day of the fiscal year and the annual average balance. This would prevent strategies of withdrawal or transfer just before the end of the fiscal year to minimize tax payments. More recently, the OECD's tax information exchange agreements (TIEAs) - in which Brazil took part in December 2016 - have strengthened the instrument of third-part reporting at the international level, enhancing enforcement against tax evasion and aggressive tax planning.

On the other hand, Saez and Zucman (2019) highlight the lack of a systematic market valuation for business assets and private corporate stock typically held by the richest households. ${ }^{5}$ However, they point to the existence of secondary markets for some of these assets and cite that countries like Switzerland have successfully taxed shares in private businesses on the basis of estimates combining the book value of business assets and a fixed multiple of profit flows.

Despite these increasing opportunities, the international trend has been towards the weakening or removal of wealth taxes. Bird (1991) notes that among 1965 and 1988, wealth and inheritance taxes dropped from $0.5 \%$ to $0.4 \%$ of GDP among OECD countries. Kessler and Pestieau (1991) argue that wealth tax revenues have been very low in Europe due to four main reasons: (1) few countries taxed corporate wealth; (2) the minimum tax threshold greatly varied between countries; (3) many countries limited the annual income share that could be taxed by both the personal income tax and the wealth tax; (4) real estate was commonly undervalued and there was no declaration of overseas properties.

Before 1990, all Western European countries had a recurrent wealth tax, with the exception of Belgium, Portugal and the United Kingdom. Since 1990, it was abolished in Austria (1994), Denmark and Germany (1997), Iceland (2005), Finland (2006), Sweden (2007), Spain (2008) and Greece (2009). Due to the fiscal crises following the global financial crisis of 2008-2009, the tax was revived in Spain (2011) and temporarily in Iceland (2010-2014). It remains in France (restricted to real estate since 2018), Luxembourg, Norway, Spain and Switzerland. In Latin America it only exists in Argentina, Colombia and Uruguay.

Table 1 shows the structure of the wealth tax in these eight countries for 2019. In all the eight countries, except Luxembourg and Uruguay, the tax base is limited to personal wealth. Argentina is the unique case where the tax does not take debt into account. In France and Spain the tax is characterized by notable exemptions and limits: income and wealth taxes combined cannot exceed a fixed share of a taxpayer's income (75\% in France and 60\% in Spain); from 2018 in France, the tax exempts financial assets; while in Spain, primary residences and certain types of in-

\footnotetext{
${ }^{5}$ The authors estimate that these assets make up about $20 \%$ of the total wealth of the richest $0.1 \%$ of households in the U.S.
} 
dividual corporate shares are exempt, while its autonomous communities can regulate exemptions to the point of offering full rebates to its taxpayers (as in the case of Madrid).

Tax thresholds greatly vary among the selected eight countries, from no threshold and a minimum levy on corporate wealth in Luxembourg, to 1,300,000 euros of individual taxable wealth in France and Colombia. Spain also has a high threshold of 700,000 euros, while in the other countries it varies from 70,000 to 280,000 euros. The tax rates are proportionate or progressive, generally being between $0.5 \%$ and $1.5 \%$.

Table 1: Main Features of Wealth Taxes (selected countries, 2019)

\begin{tabular}{lccccc}
\hline Country & Competence & $\begin{array}{c}\text { Tax } \\
\text { Base }\end{array}$ & $\begin{array}{c}\text { Tax } \\
\text { Unit }\end{array}$ & $\begin{array}{c}\text { Tax } \\
\text { Threshold }{ }^{1}\end{array}$ & $\begin{array}{c}\text { Tax Rates } \\
\text { (\%) }\end{array}$ \\
\hline Luxembourg & Central & Net Wealth & Corporate & $\begin{array}{c}\text { No } \\
\text { threshold }\end{array}$ & 0.5 \\
Switzerland & $\begin{array}{c}\text { Regional } \\
\text { and Local }\end{array}$ & Net Wealth & Personal & $180,000^{2}$ & 0.1 to 0.94 \\
Uruguay & Central & Net Wealth & $\begin{array}{c}\text { Personal and } \\
\text { Corporate }\end{array}$ & 120,000 & 0.7 to 2.8 \\
Colombia & Central & Net Wealth & Personal & $1,300,000$ & 1.0 \\
Norway & $\begin{array}{c}\text { Regional } \\
\text { and Local }\end{array}$ & Net Wealth & Personal & 120,000 & 0.85 \\
Argentina & Central & Gross Wealth & Personal & 70,000 & 0.25 to 0.75 \\
France & Central & Net Real & Personal & $1,300,000$ & 0.5 to 1.5 \\
Spain & $\begin{array}{c}\text { Central } \\
\text { and Regional }\end{array}$ & Net Wealth & Personal & 700,000 & 0.5 to 2.5 \\
\hline
\end{tabular}

Source: OECD (2018b) and Finance Ministries (selected countries). The recent tax reforms in Argentina (tax rate reduction and threshold increase) and France (tax base restriction to real estate) are not accounted for. 1 In euros of Jan 1, 2019 (market exchange rates, approximate values).

2 Canton of Geneva.

Table 2 shows that wealth tax revenues have been stable since $2000,0.8 \%$ of GDP on average (or $0.5 \%$ in median value). However, it is important to note that according to OECD data (2018b), they were about $0.45 \%$ of GDP between 1970 and 1999 amongst the 12 countries that adopted the tax (Austria, Canada, Denmark, Finland, France, Germany, Iceland, Luxembourg, Netherlands, Norway, Sweden, and Switzerland). Higher than average revenues are collected in Luxembourg, Switzerland and Uruguay. 
Table 2: Wealth Tax Revenues in selected countries, 2000-18 (\% of GDP)

\begin{tabular}{lccccccccccccc}
\hline Country & $\begin{array}{r}2000- \\
-2003^{*}\end{array}$ & $\begin{array}{r}2004- \\
\end{array}$ & 2000 & 2009 & 2010 & 2011 & 2012 & 2013 & 2014 & 2015 & 2016 & 2017 & 2018 \\
\hline Luxemburg & 2.37 & 2.26 & 1.90 & 1.94 & 2.07 & 1.99 & 2.04 & 2.10 & 2.16 & 2.52 & 2.62 & 2.73 & 2.87 \\
Switzerland & 1.20 & 1.20 & 1.19 & 1.20 & 1.17 & 1.13 & 1.12 & 1.17 & 1.21 & 1.24 & 1.26 & 1.28 & 1.33 \\
Uruguay & 0.75 & 1.01 & 1.05 & 1.18 & 1.08 & 1.06 & 1.06 & 1.06 & 1.14 & 1.11 & 1.05 & 1.01 & 0.98 \\
Colombia & 0.48 & 0.18 & 0.69 & 0.44 & 0.41 & 0.72 & 0.66 & 0.63 & 0.58 & 0.69 & 0.51 & 0.42 & 0.05 \\
Norway & 0.53 & 0.55 & 0.56 & 0.56 & 0.55 & 0.55 & 0.55 & 0.56 & 0.57 & 0.45 & 0.54 & 0.54 & 0.57 \\
Argentina & n.d. & 0.30 & 0.29 & 0.32 & 0.31 & 0.27 & 0.27 & 0.31 & 0.31 & 0.31 & 0.24 & 0.22 & 0.10 \\
France & 0.16 & 0.19 & 0.21 & 0.18 & 0.22 & 0.21 & 0.24 & 0.21 & 0.24 & 0.24 & 0.22 & 0.22 & 0.08 \\
Spain & 0.20 & 0.20 & 0.26 & 0.06 & 0.06 & 0.06 & 0.14 & 0.20 & 0.18 & 0.18 & 0.18 & 0.18 & 0.18 \\
Iceland & 0.70 & 0.10 & - & - & 0.24 & 0.37 & 0.53 & 0.47 & 0.54 & - & - & - & - \\
\hline
\end{tabular}

Source: IMF (2018) and OECD (2018b); except Argentina (2018) and Uruguay (2018).

${ }^{*}$ Average value in the period.

\section{INHERITANCE TAX}

The taxation of wealth transfers via inheritance or donation is often levied on their net-of-debt value and is divided into two categories: those levied on the overall value of the estate left over, and those levied on the inheritance received by each heir. The first, known as the Estate Tax, is more common in Common Law countries, while the second, known as the Inheritance Tax, is more common worldwide. The Estate Tax may have a proportional or progressive schedule while the Inheritance Tax is generally progressive and has selective tax rates, which generally vary according to the amount received and the relationship between the deceased and the beneficiary. Both estate and inheritance taxes are often integrated with the taxation of donations, since taxpayers could easily avoid taxation by making/receiving lifetime donations. The inheritance tax has an important distributive feature, considered to be much more important than its revenue potential. For example, Bird (1991) referring to a study using income tax data, states that the inheritance tax in Japan had a larger effect on reducing inequality than the personal income tax. Indeed, despite its generally weak revenue mobilization, inheritance taxation may prevent the excessive concentration of wealth and its income flows across generations.

After the Second World War, inheritance taxation was heavily used as a distributive instrument among advanced economies. Piketty (2014) highlights that in the United States, United Kingdom and Japan, the top marginal tax rates between 1950 and 1980 were approximately $75 \%-80 \%$, decreasing to approximately $40 \%$ 
by the 2010s, except in Japan where it fell to $55 \%$. Indeed, according to the OECD database (2018b), the ratio of inheritance tax revenues to GDP in the end of the 1960 s reached approximately $0.8 \%$ in United Kingdom (reduced to $0.2 \%$ since the $1980 \mathrm{~s}$ ), $0.6 \%$ in Australia (abolished in 1979), and $0.5 \%$ in Ireland, New Zealand and United States. ${ }^{6}$ On the other hand, the tax was strengthened in France, Belgium, Japan and Korea. For example, in France and Belgium, this ratio increased from $0.2 \%-0.3 \%$ during the 1970 s to $0.5 \%-0.7 \%$ since the 2010 s.

Although most of the economics literature states that inheritance taxation has a strong distributive effect and generates lower economic distortions than other taxes, there is a general global trend towards its weakening, due to the prevailing economic narrative that emphasizes its low revenue potential, its high administrative cost, high unpopularity and the threat of capital mobility. Being on the agenda of many political parties that were elected to power in advanced countries since the 1970s, the tax was abolished in Canada (1972), Australia (1979), Israel (1981), India and Peru (1985), Malaysia (1991), New Zealand (1992), Egypt (1996), Italy (between 2001 and 2006, and re-introduced with weaker scope since), Panama (2002), Portugal and Slovakia (2004), Russia and Sweden (2005), Hungary and Honk Kong (2006), Austria and Singapore (2008), Norway and Czech Republic (2014) and Puerto Rico (2017).

It is still important to note that statutory marginal tax rates can bear little resemblance to effective tax rates, due to the impact of thresholds, exemptions (commonly applied to the primary residence) and property undervaluation vis-à-vis market values. For example, AGN International (2010), as cited by European Commission (2011), notes that average effective tax rates on inherited wealth were substantially lower than statutory tax rates in European countries, being $22 \%$ in Belgium, around $13 \%$ in Spain, Holland and Finland, $8 \%$ in United Kingdom, Denmark and Poland, and 5\% in France and Greece.

Table 3 shows the highest statutory tax rate in 23 selected countries in 2017 for direct descendants and other heirs, as well as the exemption threshold and the top threshold applied to direct descendants. A number of points can be highlighted. Among countries of Western Europe (Germany, Spain, Ireland, United Kingdom, France and Belgium), a maximum tax rate of $30 \%-45 \%$ is applied in the case of direct beneficiaries. However, these top tax rates apply from different thresholds that vary from approximately 500,000 euros in Belgium to 26,000,000 euros in Germany. The exemption thresholds applied to direct descendants vary from less than 20,000 euros in Spain, Holland, Finland and Iceland, to over than 300,000 euros in Ireland, United Kingdom and Germany. This level of variation across countries conveys the broad range of tax progressivity applied: higher thresholds and tax rates make for a more progressive tax system.

Higher tax rates are generally applied to more distant relatives, rather than di-

\footnotetext{
${ }^{6}$ It was abolished in New Zealand in 1992 and revenues fell to about $0.15 \%$ in the United States and Ireland since the 2010s.
} 
rect descendants. In Belgium, this highest rate reaches $80 \%$, while in France and Spain it reaches $60 \%$. On the other hand, Italy re-introduced the inheritance tax in 2007 with a threshold of 1 million euros under a proportional tax rate of $4 \%$ to direct descendants and between $6 \%$ and $8 \%$ to other descendants. Among other developed countries, the United States, Japan, Korea have an average top tax rate of $50 \%$ and the thresholds of this top tax rate were on average over 3 million euros in 2017. In the listed Asian countries, the system is progressive under a threshold that starts at 75,000 euros.

Table 3: Inheritance Tax: threshold levels and top tax rates in 2017

\begin{tabular}{|c|c|c|c|c|}
\hline \multirow[b]{2}{*}{ Country } & \multicolumn{3}{|c|}{ Direct Descendants } & \multirow{2}{*}{$\begin{array}{c}\text { Others Heirs } \\
\text { Top Marginal } \\
\text { Tax Rate }\end{array}$} \\
\hline & $\begin{array}{l}\text { Exemption } \\
\text { Threshold }^{1}\end{array}$ & $\begin{array}{l}\text { Top Marginal } \\
\text { Threshold }^{1}\end{array}$ & $\begin{array}{c}\text { Top Marginal } \\
\text { Tax Rate }\end{array}$ & \\
\hline Japan & 75,000 & $4,500,000$ & $55 \%$ & $55 \%$ \\
\hline Korea & 75,000 & $2,300,000$ & $50 \%$ & $50 \%$ \\
\hline France & 160,000 & $1,800,000$ & $45 \%$ & $60 \%$ \\
\hline United States & $5,000,000$ & $5,000,000$ & $40 \%$ & $40 \%$ \\
\hline United Kingdom & 368,000 & 368,000 & $36 \%$ & $36 \%$ \\
\hline Ireland & 310,000 & 310,000 & $33 \%$ & $33 \%$ \\
\hline Spain & 8,000 & 800,000 & $32 \%$ & $64 \%$ \\
\hline Belgium & 50,000 & 500,000 & $30 \%$ & $80 \%$ \\
\hline Germany & 400,000 & $26,000,000$ & $30 \%$ & $50 \%$ \\
\hline South Africa & 235,000 & $2,100,000$ & $25 \%$ & $25 \%$ \\
\hline Chile & 56,000 & 840,000 & $25 \%$ & $35 \%$ \\
\hline Holland & 20,000 & 122,000 & $20 \%$ & $40 \%$ \\
\hline Finland & 20,000 & $1,000,000$ & $19 \%$ & $33 \%$ \\
\hline Ecuador & 50,000 & 600,000 & $17.5 \%$ & $35 \%$ \\
\hline Argentina $(\mathrm{BA})^{2}$ & 10,000 & 670,000 & $16 \%$ & $22 \%$ \\
\hline Denmark & 34,000 & 34,000 & $15 \%$ & $25 \%$ \\
\hline Iceland & 10,000 & 10,000 & $10 \%$ & $10 \%$ \\
\hline Greece & 150,000 & 300,000 & $10 \%$ & $40 \%$ \\
\hline Turkey & 37,000 & 926,000 & $10 \%$ & $10 \%$ \\
\hline Taiwan & 12,000 & 12,000 & $10 \%$ & $10 \%$ \\
\hline Colombia & $\begin{array}{l}\text { Integrated to } \\
\text { Income Tax }\end{array}$ & n.a. & $10 \%$ & $10 \%$ \\
\hline Brazil & 20,000 & n.a. & $8 \%$ & $8 \%$ \\
\hline Italy & $1,000,000$ & $1,000,000$ & $4 \%$ & $8 \%$ \\
\hline
\end{tabular}

Notes: Authors' elaboration from official sources. The table ranks countries by the level of their top marginal tax rate applied to direct descendants (i.e., children). Top marginal thresholds for Colombia and Brazil are not available, as in the former the tax is integrated to the income tax, while in Brazil top rates vary by state.

${ }^{1}$ In euros of Jan 1, 2019.

2 Only in the Province of Buenos Aires. 
It important to mention that in the United States the Estate Tax is a federal tax, but states can also have a separate tax on inheritance. In 2000, the Estate Tax was progressive under an exemption level of only US\$10,000 and a top marginal rate of $55 \%$. Since 2001, the top tax threshold has been annually increasing, reaching US\$ 3.5 million in 2009. In 2010, the tax was completely abolished, but re-introduced in the following year with a proportional rate of $35 \%$ (and subsequently increased to $40 \%$ ) and a tax threshold of approximately US\$ 5 million until 2017. In 2018, the threshold was increased to US\$ 11.2 million. This example illustrates how sensitive this tax is to legislative changes, and how large adjustments can come into effect relatively quickly.

Among the selected developing countries of Table 3, top tax rates applied to direct descendants and threshold levels were much lower than in developed countries. The top tax rates varied from $8 \%$ in Brazil to $25 \%$ in Chile and South Africa.

Table 4 shows the development of inheritance/estate tax revenues as a share of GDP. Comparing with Table 3, countries with higher tax rates and lower tax thresholds tend to generate higher revenues. For example, Belgium has a top marginal rate of $80 \%$ (30\% to direct descendants) and a lower threshold of only 57,000 euros, which have generated revenues between $0.6 \%$ and $0.7 \%$ of GDP. In contrast, since 2011, the United States government collects $0.14 \%$ of GDP in estate taxation with a top tax rate of $40 \%$ and a tax threshold of 5 million euros. Among developing countries, Brazilian inheritance tax revenues reached $0.11 \%$ of GDP in 2017 , the highest among this cohort. This greatly contrasts with South Africa, where inheritance taxation has returned only $0.04 \%$ of GDP with top tax rates of $20 \%-25 \%$ and a tax threshold 15 times higher than Brazil's. While higher revenues are generally collected by countries with lower exemption thresholds, it should be noted that this may come at the expense of lower distributive outcomes. ${ }^{7}$

Among Latin American countries, Colombia, Mexico and Uruguay do not have any specific tax levied on inheritance. However, in Colombia, inherited wealth comes under the individual income tax, with primary residences being exempted. In Mexico, only donations are under the individual income tax, while the inheritance of a real estate is under the general property transfer tax. The same occurs in Uruguay, where only the inheritance of real estate is taxed by the general property transfer tax. In Argentina, the tax was just introduced in the Province of Buenos Aires in 2011 (not including the Autonomous City of Buenos Aires).

\footnotetext{
${ }^{7}$ For example, Elinder et al., (2015) (as cited by OECD, 2018a) find that in Sweden, small inheritances received by poor taxpayers reduce inequality.
} 
Table 4: Inheritance/Estate Tax Revenue in selected countries, 1995-2018 (\% of GDP)

\begin{tabular}{|c|c|c|c|c|c|c|c|c|c|c|c|}
\hline Country & $\begin{array}{l}1995- \\
-2000\end{array}$ & $\begin{array}{l}2001- \\
-2005\end{array}$ & $\begin{array}{l}2006- \\
-2010\end{array}$ & 2011 & 2012 & 2013 & 2014 & 2015 & 2016 & 2017 & 2018 \\
\hline Belgium & 0.37 & 0.48 & 0.61 & 0.64 & 0.70 & 0.79 & 0.70 & 0.73 & 0.70 & 0.72 & 0.72 \\
\hline France & 0.42 & 0.47 & 0.41 & 0.41 & 0.43 & 0.45 & 0.48 & 0.56 & 0.55 & 0.62 & 0.61 \\
\hline Japan & 0.43 & 0.30 & 0.29 & 0.31 & 0.32 & 0.33 & 0.39 & 0.39 & 0.40 & 0.39 & 0.41 \\
\hline Korea & n.a. & n.a. & 0.24 & 0.25 & 0.37 & 0.32 & 0.35 & 0.30 & 0.33 & 0.39 & 0.41 \\
\hline Taiwan & n.a. & n.a. & n.a. & 0.17 & 0.19 & 0.16 & 0.16 & 0.20 & 0.28 & 0.29 & n.d. \\
\hline Holland & 0.28 & 0.30 & 0.29 & 0.24 & 0.21 & 0.27 & 0.23 & 0.24 & 0.26 & 0.25 & 0.25 \\
\hline $\begin{array}{l}\text { United King- } \\
\text { dom }\end{array}$ & 0.18 & 0.21 & 0.20 & 0.18 & 0.18 & 0.19 & 0.21 & 0.24 & 0.25 & 0.26 & 0.22 \\
\hline Finland & 0.23 & 0.29 & 0.27 & 0.20 & 0.25 & 0.32 & 0.24 & 0.30 & 0.24 & 0.41 & 0.30 \\
\hline Spain & 0.20 & 0.22 & 0.25 & 0.21 & 0.22 & 0.24 & 0.26 & 0.26 & 0.24 & 0.23 & 0.22 \\
\hline Germany & 0.12 & 0.16 & 0.17 & 0.16 & 0.16 & 0.16 & 0.19 & 0.21 & 0.22 & 0.19 & 0.20 \\
\hline Denmark & 0.20 & 0.20 & 0.22 & 0.26 & 0.21 & 0.21 & 0.20 & 0.26 & 0.21 & 0.20 & 0.21 \\
\hline Switzerland & 0.28 & 0.22 & 0.15 & 0.14 & 0.14 & 0.15 & 0.18 & 0.16 & 0.17 & 0.17 & 0.18 \\
\hline Ireland & 0.18 & 0.13 & 0.17 & 0.14 & 0.16 & 0.15 & 0.19 & 0.16 & 0.15 & 0.15 & 0.16 \\
\hline Iceland & 0.10 & 0.09 & 0.11 & 0.08 & 0.11 & 0.13 & 0.13 & 0.13 & 0.15 & 0.16 & 0.15 \\
\hline United States & 0.32 & 0.27 & 0.20 & 0.09 & 0.12 & 0.16 & 0.14 & 0.14 & 0.14 & 0.14 & 0.14 \\
\hline Brazil & n.a. & 0.04 & 0.05 & 0.06 & 0.07 & 0.08 & 0.08 & 0.11 & 0.12 & 0.11 & 0.11 \\
\hline Greece & 0.25 & 0.17 & 0.08 & 0.06 & 0.05 & 0.05 & 0.06 & 0.08 & 0.07 & 0.09 & n.d. \\
\hline Chile & 0.03 & 0.04 & 0.07 & 0.04 & 0.05 & 0.03 & 0.02 & 0.05 & 0.06 & 0.11 & 0.07 \\
\hline South Africa & 0.04 & 0.04 & 0.03 & 0.04 & 0.03 & 0.03 & 0.04 & 0.05 & 0.04 & 0.07 & n.d. \\
\hline Italy & 0.07 & 0.03 & 0.02 & 0.11 & 0.04 & 0.04 & 0.04 & 0.04 & 0.04 & 0.05 & 0.05 \\
\hline Turkey & n.a. & n.a. & 0.09 & 0.02 & 0.02 & 0.02 & 0.02 & 0.02 & 0.02 & 0.02 & 0.03 \\
\hline Norway & 0.09 & 0.09 & 0.09 & 0.06 & 0.06 & 0.07 & 0.06 & - & - & - & - \\
\hline Austria & 0.05 & 0.07 & 0.04 & - & - & - & - & - & - & - & - \\
\hline Sweden & 0.10 & 0.09 & - & - & - & - & - & - & - & - & - \\
\hline Portugal & 0.07 & 0.05 & - & - & - & - & - & - & - & - & - \\
\hline
\end{tabular}

Source: IMF (2018), OECD (2018b) and other sources.

\section{WEALTH AND INHERITANCE TAXES}

\section{IN BRAZIL: FEATURES AND REFORM PROPOSALS}

This section discusses in more detail the taxation of wealth in Brazil - the Tax on Large Fortunes, as introduced in the Brazilian Constitution in 1988 - and the taxation of wealth transfers - the inheritance tax levied by the state governments. We make a proposal for the implementation and reform of both types of taxes. The 
proposals are intended to be contributions to an on-going debate in Brazil, as well as in other countries.

\section{Tax on Large Fortunes}

Some valid arguments exist for the introduction of a tax on wealth in Brazil, most notably the high levels of inequality persisting in the country and the significant levels of private wealth held domestically. Moreover, the implementation of a wealth tax would be a democratic and transparent way to directly track and assess the distribution of wealth among the population. Even if revenues from the tax are relatively low from international experience, its primary function should rest on its distributive mechanisms.

The introduction of the Tax on Large Fortunes (Imposto sobre Grandes Fortunas - IGF) under the Brazilian Constitution in 1988 was strongly influenced by the French wealth tax, Impôt sur les Grandes Fortunes (1981-1986) and Impôt de Solidarité sur la Fortune (1988-2017). The Constitution of 1988 states that IGF must be implemented by a Supplementary Federal Law which requires a special quorum of one half of congressmen in both legislative houses to be passed. Nevertheless, despite two parliamentary votes, IGF has never been implemented to date. In 2017, there were 23 bills that intended to implement IGF in Brazil, 18 in the Chamber of Deputies and 5 in the Federal Senate. A bill was approved in the Senate in 1989 and forwarded to the Chamber of Deputies, but after 11 years of procedures, it was rejected by the Finance and Taxation Commission in 2000. This bill proposed to tax all net wealth above $\mathrm{R} \$ 4$ million (just under 1 million euros ${ }^{8}$ ) under progressive tax rates between $0.1 \%$ and $0.7 \%$. The main reasons for its rejection had to do with the abolition of wealth taxes in several Europeans countries during the 1990s, its alleged high administrative costs, and its low revenue potential. Subsequently, in 2008, there was another bill voted in the Commission of Economic Issues of the Federal Senate, which was again rejected, essentially for the same reasons as the previous rejected bill. However, this new bill intended to tax all net wealth above $\mathrm{R} \$ 10$ million (2.25 million euros) at a proportional rate of 1\% (Carvalho Junior, 2011; Carvalho Junior and Passos, 2018).

In 2015, the Federal Revenue Secretariat (Secretaria da Receita Federal-SRF) of the Ministry of Finance began to publish annual reports based on tabulated statistics from income tax declarations, including the net wealth (gross wealth minus debts) of Brazilian taxpayers ranked by income. ${ }^{9}$ The data are far from being perfect for the task at hand, but they suffice to fix some orders of magnitude regard-

\footnotetext{
${ }^{8}$ All conversions from R\$ (BRL) to euros were set as market values of Jan 1, 2019 (1 euro = 4.44 BRL).

${ }^{9}$ About $46 \%$ of total gross wealth comprised of financial assets, $37 \%$ comprise immovable property, and $7 \%$ comprised of vehicles. Total declared debts accounted for about $10 \%$ of gross wealth. Reported gross wealth corresponds to $122 \%$ of GDP, while reported debt to represents $14 \%$ of GDP.
} 
ing the potential tax base of wealth. They reveal that the wealth distribution among income taxpayers is more concentrated than its income equivalent, which is already one of the most concentrated in the world. According to the latest report relating to incomes of 2017 (SRF, 2018), approximately the top 1\% of these income taxpayers $(320,178$ taxpayers with a monthly income above $\mathrm{R} \$ 56,000(12,600 \mathrm{eu}-$ ros)) received $22 \%$ of reported income and $34 \%$ of reported net wealth. Furthermore, the top $0.1 \%$ of these taxpayers concentrate $10 \%$ of income and $17 \%$ of wealth. ${ }^{10}$ Their average wealth amounts to almost 60,000 multiples of the monthly minimum wage. ${ }^{11}$

An effective wealth tax of $3 \%$ on the net wealth of these $0.1 \%$ taxpayers would mechanically equate to $0.63 \%$ of GDP. Factoring in potential behavioral effects on the amount levied would lower this figure. Assuming the same effect that Londoño-Velez and Ávila-Macheca (2018) estimate for Colombia - a 20\% loss of projected revenues from a $1 \%$ wealth tax - and accounting for strong enforcement, third-party reporting and the TIEAs that Brazil has signed with 51 countries, the revenue estimate could be closer to $0.5 \%$ of GDP. This scheme would mainly affect approximately 30,000 taxpayers with a stock of wealth above R $\$ 50$ million (11.3 million euros).

Thus, a proposal to be examined would be the introduction of an annual tax on net wealth above a high initial threshold to target the super-rich, thus making it highly progressive and salient. The tax would apply on total household wealth to avoid intra-household portfolio re-allocations. Single person households would face lower thresholds (e.g., the proposed thresholds divided by 2 ). The schedule could contain four brackets, each expressed as multiples of the monthly minimum wage, starting at $0 \%$ and reaching $4 \%$, thus making it more progressive than existing international schedules.

Table 5 displays our proposed schedule. All assets should be determined at their current market value, with appropriate registries of real estate in place. ${ }^{12}$ The bracket values are defined as multiples of the monthly minimum wage and are expressed in effective tax rates (not marginal rates) applied to the total value of wealth net of

\footnotetext{
${ }^{10}$ It should be noted that the concentration among all Brazilian adults, not just those making income tax declarations, is likely to be much higher. Roughly $20 \%$ of the adult population is covered in the income tax statistics in Brazil. Assuming that the remaining $80 \%$ of adults have 0 net wealth, the top $1 \%$ of all adults would hold about $50 \%$ of net wealth, with the top $0.1 \%$ amassing about $30 \%$. Some caution with these wealth inequality estimates is necessary as the assets and debts declared in personal income tax returns are valued at their cost of acquisition, not necessarily their up-to-date market values, which can underestimate wealth values. In addition, the tabulations are ranked by total income, so there is likely to be re-ranking issues given the lack of a perfect correlation between the distribution of income and wealth. Only access to better data on wealth would allow us to make more precise estimates.

${ }^{11}$ One minimum wage was equal to R\$ 937 (211 euros) as of Jan 1, 2017.

12 Unlikely other wealth tax systems applied worldwide, primary residences would not be exempted in our proposal since the first tax threshold is already very high.
} 
debt liabilities of households. ${ }^{13}$ Fortunes among each scale would be taxed progressively, such that the effective tax rate evolves in a smooth manner along the wealth distribution, without the threshold jumps that are present in marginal tax rate schedules. For example, a person possessing a fortune equal to $150,000 \mathrm{~min}$. wages, halfway between 50,000 and 250,000 min. wages, would pay an effective rate of $2.5 \%$, halfway between $2 \%$ and $3 \%$. The top rate of $4 \%$ would approximately affect Brazilian billionaires (those with over 225 million euros in net wealth).

Table 5: Proposed Schedule of the Tax on Large Fortunes

\begin{tabular}{cc}
$\begin{array}{c}\text { Accumulated wealth } \\
\text { (as multiples of monthly min. wage) }\end{array}$ & Effective tax rate \\
\hline 20,000 & $0 \%$ \\
50,000 & $2 \%$ \\
250,000 & $3 \%$ \\
$1,000,000$ & $4 \%$ \\
\hline
\end{tabular}

Source: Authors' elaboration.

One minimum wage was equal to R\$ 998 (225 euros) in Jan 1, 2019.

Immediate distributive effects of a recurrent wealth tax of this nature are typically small, as they effect a small number of households - the top $0.1 \%$ income taxpayers would see their wealth share decline by half a percentage point or less in the first year. But compounded over time, the lower growth rate of their after-tax wealth would lower their share more significantly. If potential liquidity problems arise, this may force individuals to sell part of their assets thus contributing to further deconcentrate wealth. However, judging from the SRF statistics it is unlikely that liquidity problems would arise given the average income levels of the population likely to bear the tax. For instance, the average wealth tax bill corresponding to the wealth in last income bracket would be about $\mathrm{R} \$ 1.6$ million, while the average income of this group (25,000 people) is about $\mathrm{R} \$ 11.5$ million. A proper analysis of the joint distribution of income and wealth using microdata (currently unavailable) would improve assessments of liquidity, and better inform whether thresholds could be modified or whether effective tax rates at the top could increase further.

To confront tax avoidance, the SRF already avails of a registry of financial assets - the Declaração de Informações sobre Movimentação Financeira (DIMOF) which are the assets most susceptible to evade taxes. The tax office thus knows the owners and jurisdiction of the financial assets of households included in the income

\footnotetext{
${ }^{13}$ We include an initial bracket from 20,000 to 50,000 min. wages with an effective tax rate from $0 \%$ to $2 \%$, which minimizes the threshold effect. According to SRF (2018), this lower bracket would have about 10,000 taxpayers while the remaining brackets would have about 30,000 taxpayers.
} 
tax declarations. This monitoring program could be expanded to cover all privately-owned financial assets.

However, wealth hidden in offshore tax havens presents a notable challenge. The best estimates available attribute the offshore wealth of Brazilians to be $6.2 \%$ of GDP in 2007, 5.1\% of which is located in Switzerland (Alstadsæter, Johannesen, and Zucman, 2018). This total is lower than the world average of $9.8 \%$ and the Latin American average of $13 \%$, being one of the lowest among the big Latin American economies. Only Chile at $6 \%$ of GDP is lower (in comparison, Argentina's share is $37 \%$ of GDP). Nevertheless, $6.2 \%$ of GDP remains substantial. Assuming the same share in 2019 equates to R \$ 452 billion (101 billion euros) of wealth. Although no estimates have been made on its distribution, it is likely that this wealth is highly concentrated at the top end.

Therefore, to increase the scope of the wealth tax, Brazil should continue to cooperate with foreign tax authorities to put an end to cross-border evasion, following its 2016 commitment to the OECD's TIEAs. To fully curb this problem more action will be needed. For example, proposals for the automatic exchange of bank information with tax havens, enforced through commercial sanctions by regional coalitions and verified by a "world financial registry" under the supervision of an international public organization, should also be pushed for (Zucman, 2015). ${ }^{14}$ However, it should be noted that this international cooperation is not strictly necessary for Brazil to enact its own wealth tax legislation. Domestic financial regulation would go a long way to establishing a solid tax base. Furthermore, unilateral sanctions on tax havens from a country of Brazil's economic size and importance - ranging from prohibitive tariffs on their goods to the removal of their service licenses on domestic territory (e.g., banking) - would be feasible and effective (ibid.).

\section{Tax on Inheritance}

As third section evidenced, some form of taxation of inheritance and inter-vivos donations exists or has existed in most countries. Brazil is no exception, with the Imposto sobre Transmissão Causa Mortis e Doação (ITCMD) being created by the 1891 Constitution and regulated in 1898 with tax rates between $0.5 \%$ and $22 \%$, varying according to state and to the relationship between the donor and the recipient. In the Federal District (Rio de Janeiro up to 1960 and Brasilia since), this range was increased from $3 \%$ to $38 \%$ in 1940 , and from $2 \%$ to $65 \%$ in $1962 . .^{15}$ The states of Santa Catarina (1957-1965), São Paulo (1932-1965), and Minas

\footnotetext{
${ }^{14}$ A world financial registry would in effect identify the owners and jurisdiction of all global financial assets in circulation, allowing national fiscal administrations to verify that their contributors have honestly declared all their financial assets inscribed in the registry.

${ }^{15}$ Federative Republic of Brazil $(1940,1962)$. Article $5^{\text {th }}$ of Federal Decree-Law 2,224/1940 and Article 76 of Federal Law 4,191/1962. In this latter law, the exemption limit was defined up to 5 times the minimum wage of the Federal District.
} 
Gerais (1939-1965) also had progressive systems in the past, with top marginal rates of $32 \%, 42 \%$, and $60 \%$, respectively, despite lower rates for transfers to children and/or spouses (State of Santa Catarina, 1956; State of São Paulo, 1931, 1935; State of Minas Gerais, 1938, 1947).

However, ITCMD experienced notable changes over time. The main change came about by the $18^{\text {th }}$ Constitutional Amendment of 1965 (during the military dictatorship), which limited the tax base to immovable properties and reduced the tax rate to a proportional level of $2 \%$. Its current form derives from the 1988 Constitution. It is a state-level tax, levied by each state government on all inherited wealth or donated inter-vivos transfers, according to its own discretionary schedule. The only common feature was defined by the Federal Senate Resolution No. 9 of 1992, which establishes the maximum marginal tax rate of $8 \%$ across states, which is very low by current and historical international standards. ${ }^{16}$ This same resolution permits progressive tax rates (increasing by levels of inheritance/donations received by each beneficiary), and more states have been moving to a progressive schedule. However, the Federal Supreme Court (Supremo Tribunal Federal STF) defined as unconstitutional the tax rate differentiation per degree of relationship (STF, 2015).

According to ITCMD state legislations, the top marginal tax rates in 2017 were $2 \%$ in one state, $4 \%$ in ten states, between $5 \%$ and $7 \%$ in six states and $8 \%$ in ten states (Carvalho Junior, 2018). In addition, the threshold and exempted assets also vary. The exemption threshold was zero in ten states, but was $\mathrm{R} \$ 192,000$ $(43,243$ euros) in Mato Grosso. Primary residences are completely exempt in six states while 18 states exempt low-valued residences (values that vary from R $\$$ 20,000 (4,504 euros) in Santa Catarina to $\mathrm{R} \$ 477,000$ (107,432 euros) in Acre). Indeed, on average, the ITCMD represented less than $1 \%$ of state revenues and only little more than half of Brazilian states operate a progressive system (Ibid.).

SRF (2018) also includes data on inheritance and donations received by income taxpayers. ${ }^{17}$ These data show that about 345,035 of income taxpayers $(1.2 \%$ of the total, and $0.2 \%$ of the national adult population) received inheritance/donation transfers in 2017 amounting to $\mathrm{R} \$ 306,058$ (68,932 euros) on average (almost 3 times the average declared income). The distribution of the transfers among these taxpayers is striking: $76 \%$ of total transfers were received by the richest $10 \%$, including $52 \%$ for the top $1 \%$ (whose average receipts amounted to almost $\mathrm{R} \$ 20$ million (4.5 million euros), over 100 times the average declared income) and 32\%

\footnotetext{
${ }^{16}$ Furthermore, the tax thresholds are also very low for international standards and there is no tax differentiation per degree of relationship. Since 2015, the ratio of Brazil's inheritance tax to GDP is the highest amongst developing countries (see Table 4). However, such low thresholds and rates make its inequality impact quite low.

${ }^{17}$ As opposed to the data on wealth, inheritance and donation recipients are ranked by increasing intervals of total transfers, as well as being ranked by total income.
} 
for the top $0.1 \%$ (whose average receipts were $\mathrm{R} \$ 97$ million ( 21 million euros), about 500 times the average declared income).

Given this context, our proposal would be to reform the current inheritance and donations tax into a federal lifetime capital receipts tax, similar to the one envisaged by Atkinson (2015). ${ }^{18}$ Table 6 conveys an illustrative schedule of what this tax could look like in the Brazilian case. It would be a tax on the amount of inheritance transfers and donations received (capital receipts) each year, where the tax to be applied depends on lifetime receipts. This means that "every legacy or gift received by a person would be recorded from the date of initiation of the tax, and the tax payable determined by the sum received to date" (Morgan, 2018, p. 194).

Table 6: New Inheritance Tax Schedule (Lifetime Capital Receipts Tax)

\begin{tabular}{cc}
\hline $\begin{array}{c}\text { Accumulated capital receipts } \\
\text { (as multiples of monthly min. wage) }\end{array}$ & Effective tax rate \\
\hline 50 & $0 \%$ \\
100 & $20 \%$ \\
250 & $25 \%$ \\
500 & $30 \%$ \\
1,000 & $35 \%$ \\
2,000 & $40 \%$ \\
10,000 & $45 \%$ \\
25,000 & $50 \%$ \\
\hline
\end{tabular}

Source: Authors' elaboration.

One minimum wage was equal to R\$ 998 or 225 euros, as of Jan 1, 2019.

Similar to the wealth tax proposal in Table 5, the schedule is expressed in effective tax rates, rather than marginal tax rates. To give an example, suppose a person received $\mathrm{R} \$ 40,000$ from a relative's estate in 2018. This would be below the taxable level of this schedule applied, in which case no tax is paid. Suppose in 2019, the person received a donation of $\mathrm{R} \$ 34,850$, which brings the total received to $\mathrm{R} \$$ 74,850 . This brings the lifetime total to $75 \mathrm{~min}$. wages, which would bear a $10 \%$ tax. This process would be repeated in each year for all recipients.

The top effective rate of $50 \%$ is lower than the top marginal rate of $65 \%$ applied in the Federal District (Brasilia) over a short 3-years period (1962-1965), and in line with the top rates currently applied in the U.K. the U.S. and Japan. Exemptions could be considered for the transfer of residential property (up to certain value) used as primary residence by the recipient, as well as transfers between spouses or civil partners. Where the tax payable is greater than the cash flow of the individual, a provision to pay in the form of an equity stake in the value of the asset could be installed.

\footnotetext{
18 The following proposal is a minimally modified version of the one first presented in Morgan (2018). Receipts from the tax could be distributed to the state budgets in proportion to amounts collected from each.
} 
Such a system would incentivize transferring movable property in small amounts across more receivers, which would better regulate the transmission of inequalities from one generation to the next. Concerning the transfer of business capital (in family-owned firms or other companies in the form of shareholdings), the new lifetime capital receipts tax would directly encourage a dilution of ownership into smaller stock participations. Otherwise, the government could directly receive equity in the firms equal to the value of the tax payable, and subsequently offer the shares to the workers in the firms at discounted prices. This would help broaden capital ownership across the population.

In terms of the magnitude of resources levied, SRF (2018) calculates that in 2017 all inheritances and donations declared by taxpayers were of the order R\$ 105.6 billion (23.7 billion euros) in total, and therefore an effective tax of $30 \%$ would levy $0.48 \%$ of GDP. Accounting for reasonable behavioral effects of such a tax (more widespread receipts, diluting ownership, avoidance and evasion) a revenue level of $0.35 \%$ of GDP could be feasibly achieved ( $\mathrm{R} \$ 23$ billion, or 5.2 billion euros in 2019). It should be noted, that with avoidance and evasion minimized through enforcement, inequality could be improved ex-ante from behavioral changes in the accumulation of wealth and distribution of estates, or ex-post via the operation of the tax. The latter channel would have notable immediate effects on the distribution of inheritances/donations. We estimate that the share of the richest $10 \%$ of inheritors in the population of receivers in the SRF statistics would decline from $76 \%$ to about $68 \%$, the share of the top $1 \%$ from $52 \%$ to $42 \%$, and the share of the top $0.1 \%$ (345 persons) from $32 \%$ to $24 \%$. Similar magnitudes can be found when ranking inheritance receipts by total income, suggesting little concern for liquidity problems for these taxpayers as they are also income rich.

\section{CONCLUSION}

This article presented global perspectives on both wealth and inheritance taxes, analyzing their status in Brazil and making reform proposals. Despite the previous existence of wealth taxes in most countries of Western Europe and some countries of South America (Argentina, Colombia and Uruguay), currently the tax only remains in Switzerland, Luxembourg, Norway, Spain, Argentina, Colombia and Uruguay. In Brazil, the wealth tax (i.e., the "Tax on Large Fortunes" (IGF)) figures in the 1988 Constitution, but it has never been implemented.

There is also a global trend to weaken inheritance taxation, since many developed countries have abolished or reformed the tax, such as Australia, Austria, Canada, Italy, New Zealand, Norway, Portugal, Sweden and the United States. These countries already had higher inheritance taxation during the $20^{\text {th }}$ century and they are not as unequal as Brazil. In addition, there are other developed countries where inheritance taxation still remains strong, such as Belgium, France, Japan, and United Kingdom. Paradoxically, subnational revenue indicators of the inheritance tax in Brazil reveal an increasing trend in recent years, mainly due to improvements in the tax administration and to rising rates, but its distributive effect is likely to be 
mild since the highest legally permitted statutory tax rate of $8 \%$ is very low by international historical standards.

Nevertheless, the wealth data in the income tax statistics reveal that Brazil has an extremely high wealth concentration, and the IGF revenue potential of over $0.5 \%$ of GDP under the proposed scheme of this study is not insignificant, being almost the amount levied by the current urban property tax (IPTU) in 2018. Our proposal for the wealth tax considers a progressive schedule on the $0.1 \%$ richest taxpayers. Adding at least a further $0.35 \%$ of GDP from a reformed inheritance tax (an amount close to that of Japan), a national system of taxation on personal wealth possession and transfer could re-direct $0.85 \%$ of GDP, which is significant.

However, the importance of wealth taxation goes beyond the mobilization of revenues. The perspectives on tax reform presented in this article are first and foremost intended to open up space for ideas and debate. The proposals sketched out should be seen as blueprints for a more socially just and economically efficient tax system. It is important to envisage the reforms as one part of a broader policy space agenda. A more complete fiscal revamp would integrate the spending side of fiscal policy into the equation. While the latter is beyond the scope of this article, it is crucial not to lose sight of it. As highlighted by Morgan (2018), taxation is a tool to stabilize prices, influence behaviors - including income remunerations and asset accumulations - and to open up fiscal space for the government to pursue its social objectives when resources are fully employed in the economy.

There is no doubt that making these reforms in a country that is still underdeveloped and carrying very high levels of inequality is a tall order. Indeed, this consideration made Kaldor (1963) ponder whether progressive taxation is only applicable when a country has reached an advanced stage of development. But as the author recognized, even at a lower stage of development, countries with a high concentration of resources will always have taxable capacity, which the average income indicator of a country does not reveal. Therefore, the choices facing the country are located in creating the administrative capacity for enforcement and collection, as well as fostering the political capacity to make the reforms. If Brazil was able to apply high progressive tax rates (on income and inheritance) in the mid $20^{\text {th }}$ century, there is no reason why it cannot do it in the $21^{\text {st }}$ century.

However, the central element to put things in motion in a democracy, as Kaldor recognized, was political power: "The problem which has yet to be solved is how to bring about that change in the balance of power which is needed to avert revolutions with having a revolution?"'(Kaldor, 1963, p. 419) This would depend on the aversion of the ruling classes to social instability, and the power of elites over policymakers and the economy more generally, either through institutional outlets (media, think tanks, campaign finance, etc.) or through their concentration of investment and employment.

Out of all the mechanisms imaginable to change a society's vertical structure, and its concentration of power, the progressive tax is one of the most peaceful and democratic. Over the $20^{\text {th }}$ century it became one of the central pillars of social democratic parties around the western hemisphere, not attracted by the state-communist solution, including in less advanced countries such as Brazil (and others in Latin America). This is because many social thinkers of that century identified that 
inherent instability is the result of political democracies that do not democratize their economic systems and forge plutocracies instead. This state of affairs only increments social tension further and can breed the rise of violent transitions or regimes. It can be argued that the Second World War served as the turning point for social democracy, in seeking to prevent the rise of fascism again in the future. Brazil should not need to count on a violent conflict to implement progressive policies in the interests of broad segments of society. Yet, in the prevalent COVID-19 crisis, the under-exploited taxation of top wealth is likely to become a more salient policy option.

\section{REFERENCES}

AGN International. 2010. Inheritance Tax - 2010: A European Comparison.

Alstadsæter, A.; Johannesen, N.; Zucman, G. (2018). Who Owns the Wealth in Tax Havens? Macro Evidence and Implications for Global Inequality. Journal of Public Economics, 162, 89-100.

Alvaredo, F.; Chancel, L.; Piketty, T.; Saez, E.; Zucman, G. (2018) World Inequality Report 2018. Harvard University Press, 2018.

Barros, R.P.; Mendonça, R. (1995) “Os determinantes da desigualdade no Brasil”. Rio de Janeiro: IPEA (TD 377). https://bit.ly/2QOyffg

Bastani, S.; Waldenström, D. (2019). Salience of Inherited Wealth and the Support for Inheritance Taxation (Mimeo). http://bit.ly/364gIEQ

Bird, Richard M. (1991) "The Taxation of Personal Wealth in International Perspective”, Canada Public Policy: Analyse de Politiques XVII:3, 322-34.

Bowles, S. (2012). "The new economics of inequality and redistribution", Cambridge University Press.

Brülhart, M.; Gruber, J.; Krapf, M.; Schmidheiny, K. (2019) "Behavioral Responses to Wealth Taxes: Evidence from Switzerland”, CESifo Working Paper Series 7908. https://bit.ly/39bakwQ

Carvalho Junior, P.H.B. (2011) As discussões sobre a regulamentação do Imposto sobre Grandes Fortunas: a situação no Brasil e a experiência internacional. Brasília: IPEA (Nota Técnica).

Carvalho Junior, P.H.B.; Passos, L. (2018) O Imposto sobre Grandes Fortunas, In: Fagnani, E. (Org.), A Reforma Tributária Necessária: diagnóstico e premissas. Brasília: ANFIP, FENAFISCO, PPS, p. 475-488.

Carvalho Junior, P.H.B. (2018). O Imposto sobre Herança. In: E. Fagnani (ed). A Reforma Tributária Necessária: diagnóstico e premissas. São Paulo: ANFIP, FENAFISCO, PPS, p. 457-74.

Denk, O. 2012 “Tax Reform in Norway: A Focus on Capital Taxation”, OECD Economics Department Working Papers, No. 950, OECD Publishing, Paris. https://bit.ly/3aeQH8q

Diamond, P.; Saez, E. (2011) "The case for a progressive tax: from basic research to policy recommendations", Journal of Economic Perspectives, 25 (4): 165-190.

Durán-Cabé, J.M.; Esteller-Moré, A.; Mas-Montserrat, M. (2019) "Behavioral responses to the (re)introduction of wealth taxes: Evidence from Spain”, IEB Working Paper 2019/4. https://bit. ly/2UcAivp

Elinder, M.; Erixson, O.; Waldenström, D. (2015) Inheritance and wealth inequality Evidence from population registers. Uppsala Center for Fiscal Studies Department of Economics (Working Paper 2015:3).

European Commission. (2011) Study on Inheritance Taxes in EU Member States and Possible Mechanisms to Resolve Problems of Double Inheritance Taxation in the EU. EC Directorate-General for Taxation and Customs Union (Principal author H. Sigurd).

Fairfield, T. (2015) Private Wealth and Public Revenue. Cambridge University Press.

Federative Republic of Brazil. (1940) Federal Decree-Law 2,224 of 1940. http://bit.ly/389mQxx

Federative Republic of Brazil. (1962) Federal Law 4,191 of 1962. http://bit.ly/34U3URd

Gobetti, S.W.; Orair, R. O. (2017) “Tributação e distribuição de renda no Brasil: novas evidências a partir de dados da DIRPF”, Brazilian Journal of Political Economy, v.37, n.2, p.267-286. 
Gronau, R. (1977) "Leisure, Home Production, and Work: the Theory of the Allocation of Time Revisited", Journal of Political Economy, 85(6): 1099-1123.

Hoffmann, R. (2002) “A distribuição da renda no Brasil no período 1992-2001”, Economia e Sociedade, v. 11, n. 2 (19): 213-235. https://bit.ly/2xsdE9H

Iara, A. (2015) "Wealth distribution and taxation in EU countries", Taxation Paper 60/2015, European Commission. https://bit.ly/2UuZdJH

IMF (International Monetary fund). (2018) Government Finance Statistics Database.

Jacobs, B. (2013) "From optimal tax theory to applied tax policy", FinanzArchiv: Public Finance Analysis, 69 (3): 338-389.

Jakobsen, K.; Kleven, H.; Zucman, G. (2018) "Wealth Accumulation and Wealth Taxation: Theory and Evidence from Denmark” NBER Working Paper 24371.

Kaldor, N. (1963) “Will Underdeveloped Countries Learn to Tax?” Foreign Affairs, 41(2): 410-419.

Kessler, D; Pestieau, P. (1991) "The Taxation of Wealth in the EEC: Facts and Trends", Canada Public Policy: Analyse de Politiques. v. XVII:3, 309-21.

Londoño-Velez, J.; Avila-Mahecha, J. (2018) Can Wealth Taxation Work in Developing Countries? Quasi-Experimental Evidence from Colombia. (Working Paper). http://bit.ly/2OVrDLw

Medeiros, M. (2006) "The rich and the poor: the construction of an affluence line from the poverty line", Social Indicators Research, 78(1): 1-18.

Morgan, M. (2017) "Income Inequality, Growth and Elite Taxation in Brazil: New Evidence Combining Survey and Fiscal Data, 2001-2015.” IPC-IG Working Paper, No. 165. Brasília: International Policy Centre for Inclusive Growth.

Morgan, M. (2018) "Perspectivas da Reforma Tributária no Brasil”, In: Fagnani, E. (ed). A Reforma Tributária Necessária: Justiça Fiscal é Possível: Subsídios para o Debate Democrático sobre o Novo Desenho da Tributação Brasileira. São Paulo: ANFIP, FENAFISCO, PPS, p. 119-131.

OECD (Organisation for Economic Co-operation and Development). (2018a) "The Role and Design of Net Wealth Taxes in the OECD", OECD Tax Policy Studies, No. 26.

OECD (Organisation for Economic Co-operation and Development). (2018b) Revenue Statistics Database, 2017.

Oxfam (2014). "Working for the few: political capture and economic inequality", Oxfam Briefing Paper 178. https://bit.ly/3budoFY

Piketty,T. (2014) Capital in the Twenty-First Century. Harvard University Press.

Rudnick, R.S.; Gordon, R.K. (1996) “Taxation of Wealth”, In: Thuronyi, V. (ed). Tax Law Design and Drafting (1). IMF (Chapter 10).

Saez, E; Zucman, G. (2019) How would a progressive wealth tax work? Evidence from the economics literature. (mimeo). http://bit.ly/2sPc4fI

Seim, D. (2017) "Behavioral Responses to an Annual Wealth Tax: Evidence from Sweden”, American Economic Journal: Economic Policy, 9(4): 395-421.

Soares, S.S.D. (2010) “O ritmo na queda da desigualdade no Brasil é aceitável?, Revista de Economia Política 30(3): 364-380.

Souza, P.H.G.F. (2018) Uma História De Desigualdade: A Concentração De Renda Entre Os Ricos No Brasil, 1926-2013. Hucitec, São Paulo.

SRF (Secretaria da Receita Federal). (2018). Grandes Números IRPF - Ano-Calendário 2017, Exercício 2018. CETAD - Centro de Estudos Tributários e Aduaneiros. Ministério da Fazenda. Brasília.

State of Minas Gerais. (1938) State Decree 67 of 1938. http://bit.ly/2sQNUS3

State of Minas Gerais. (1938) State Decree 67 of 1947. http://bit.ly/367DhbE

State of São Paulo. (1931) State Decree 5,101 of 1931. http://bit.ly/2YmcGVV

State of São Paulo. (1935) State Decree 7,274 of 1935. http://bit.ly/365yxU4

State of Santa Catarina. (1956). State Law 1,624 of 1956. http://bit.ly/2DQAZ4E

STF (Superior Tribunal Federal). (2015) Judgment of Extraordinary Appeal, RE Agr No. 854,869/PE, STF Official Gazette, August 25.

Zoutman, F.T. (2018). "The Elasticity of Taxable Wealth: Evidence from the Netherlands", Working Paper (R\&R at Scandinavian Journal of Economics). https://bit.ly/2UyzwI2

Zucman, G. (2015) The Hidden Wealth of Nations. University of Chicago Press. 